\title{
小流域分析に基づく神田川上流域の緑地施策の歴史的経緯と今後の計画論に関する研究
}

\section{A Study on the Historical Evolution of Green Space Planning and Perspectives for the Planning in the Upper River Basin of the Kanda River based on the Small Watershed Analysis}

\author{
石川幹子*＼cjkstart森田楓菜** 山本遼介*
}

Mikiko ISHIKAWA Kana MORITA Ryosuke YAMAMOTO

\begin{abstract}
The purpose of this paper is to clarify the structure and characteristics of green infra structure in the upper river basin of the Kanda River in Tokyo from the point of the historical evolution of Green and Water conservation policies, and considers the effective methodology of green infrastructure planning, towards the adaptation of the climate change. The following three points have clarified. The first is the structure of the target area has been developed based on five small watersheds. Through the implementation of various green conservation policies, the structure, namely, core, corridor, and matrix has been gradually formulated. The second is, it is important to develop precise strategies based on the characteristics of each watershed. The third is, for contributing to solve the earth problems, such as enriching bio-diversities, enlarging water permeability, and protecting cultural landscapes, to create GI map is essential, since it would create the common platform between various stakeholders., and it becomes possible to introduce the simulation towards the climate change. By creating several scenarios, we could testify the future of the region, and consider alternative futures for the adaptation of the climate change.
\end{abstract}

Keywords: green space conservation, parks and open spaces planning, small watershed, green coverage,

The Kanda River, green infrastructure

キーワード：緑地保全, 公園緑地計画, 小流域, 緑被率, 神田川, グリーンインフラ

\section{1. 背景と目的}

都市における緑地は，環境保全，レクリエーション，防災，景 観等，多様な役割を有しているが，近年，生物多様性の向上，水 循環の回復, 温暖化に伴う都市気象の変化への対応 (都市型水害) 等, より多様な役割が求められるようになってきている。このよ うな社会的背景を踏まえて，近年，グリーンインフラストラクチ ヤー（以下 GI と表記する）に関する政策が，各国で展開されて いる。

欧州委員会では，「GI とは，水の浄化，大気の質，レクリエー ションの場, 気候変動への緩和・適応等, 広範なエコシステム・ サーヴィスに資する戦略的に計画された自然的・半自然的ネット ワークである」1)と定義しており，これを踏まえてEU各国では，

それぞれの国の実情に応じた施策展開を行っている。ドイツでは 16 の州が施策展開を行っており，実現された GI としては，ライ プチッヒ市における都市内空地の再生事業, 工業の衰退に伴うル 一ル地方におけるエムシャ一流域圈再生事業，エルベ川の氾濫原 保全等が事例としてあげられる。イギリスでは，ナチュラル・イ ングランドが，GIの考え方を提示しており，「GI とは多様な機能 を有し，コミュニティに恩恵を与え，生活の質を高めるものであ る」2) と定義されており，木下等 3 は, リバプール市における小地 域を対象とした計画手法の研究を行っている。アメリカ合衆国環 境保護局では，「GI とは都市において降雨の土壌浸透を促し，降 雨を貯留し, 洪水などの 水管理, 水質污染を防ぐものである」4) と定義している。

日本においては，国土形成計画 5)，第 4 次社会資本整備重点計 画6)で GI がとりあげられ，2019 年には GI 推進戦略 7)が取りま とめられた。「GI とは, 社会資本整備や土地利用等のハード・ソ フト両面において，自然環境が有する多様な機能を活用し，持続 可能で魅力ある国土・都市・地域づくりを進める取組である」と されている。

このように, GI に関する取り組みは, 世界各国で, 社会的要請,
地域の自然環境の特性により多様である。

そこで, 本研究は, GI の意味と構造について検討を深めるため に，社会資本整備の中で形づくられてきた既存市街地の緑地や水 環境について，歴史的に形成されてきた保全施策の積み重ねから 分析を行い, GI の特色を明らかにし, 今後の緑地保全・創出施策 の展開に向けた，基礎的研究を行うことを目的とする。

\section{2. 対象地と既往研究}

研究の対象地は, 東京都神田川流域の上流部にあたる, 神田川, 妙正寺川の合流地までとした（図一1）。当該地域は, 明治以降の 近代化に伴い農耕地の都市化が進展し, その過程で, 様々の緑地 保全, 水環境保全施策, 及び基盤整備事業が, 導入された地区と, されなかった地区が混在しており, 施策の歴史的分析に関わる豊 富な事例が存在していることによる。

当該地域に関する既往研究としては, 神田川上流域に存在する 5 つの小流域のうち(図-2), 神田川小流域と善福寺川小流域に ついは，竹内 8)が公園緑地施策の歴史的展開について，石川等 9)が生物多様性について，飯田等 10)が都市緑地の有する雨水浸透 機能と内水汇濫抑制効果について研究を行っている。しかし，神 田川上流域における 5 つ小流域全体を対象とし, 緑地と水環境 の特質について，分析を行った研究は存在していない。当該地域 には，井の頭池を水源とする神田川，善福寺池を水源とする善福 寺川, 妙正寺池を水源とする妙正寺川があり, 江古田川及び桃園 川（現在は覆蓋されて消滅）は源頭水源となる池を有さない河川 である。

\section{3. 研究の方法}

（1）小流域分析の導入

図一1 は, 1909 年の土地利用に小流域の境界を表示したもので ある。この図面から, 当該区域は上記の 5 河川が武蔵野台地を開 析し形成された農業地帯が, 20 世紀初頭まで維持されていたこと

*中央大学研究開発機構 **崎市建設緑政局 


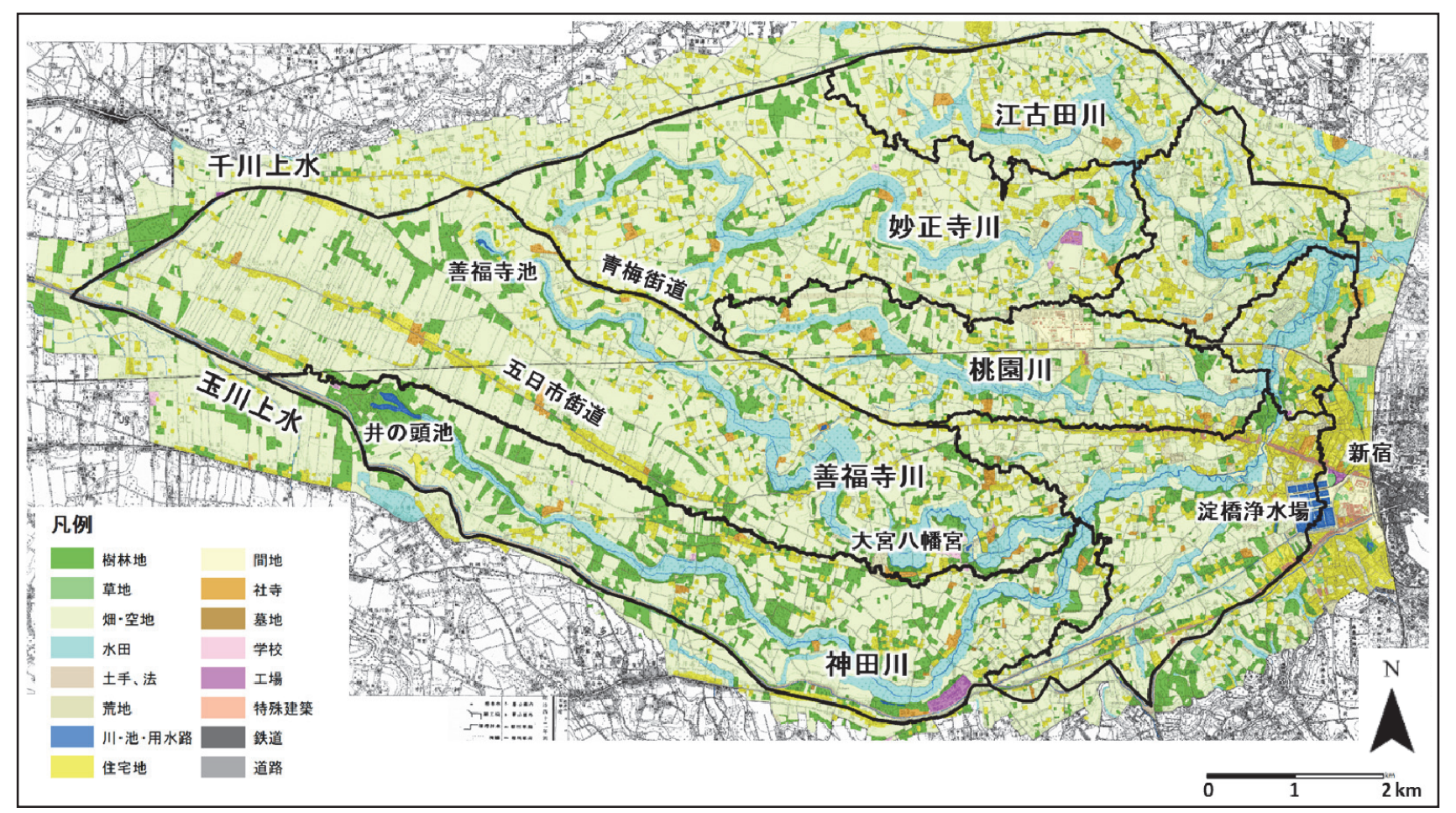

\section{図-1＼cjkstart対象地の位置と小流域（1909 年）}

がわかる。すなわち, 台地上は畑・集落・街道, 崖線には斜面林, 沖積低地には水田，崖線の突端部には社寺が分布していた。各小 河川流域の分水嶺は, 青梅街道, 五日市街道, 玉川上水，千川上 水となっており，小流域の枠組み，そのものが，水利用や農業を 支え，地域構造の基盤を形成していたことがわかる。関東大震災 以降の都市化は，長い農耕社会が形成してきた，この基盤上に展 開されたものであり, 本研究に当たっては, 江戸以来 400 年に渡 り形成されてきた枠組みを下敷きとすることが適切であると判断 した。

\section{（2）小流域区分図の作成}

小流域区分は, $5 \mathrm{~m}$ メッシュの標高データ DEM データ (Digital Elevation Model）を元に, ArcGIS 10.5 の Spatial Analysis ツー ルの水文解析プログラムを用いて行った。

\section{（3）土地利用の歴史的変遷}

土地利用の歴史的変遷を分析するために, 1909 年の帝国陸軍参 謀本部作成の図面をデジタル化し，当時の土地利用を作成し， 2011 年の東京都 GIS データ 11) との比較検討を行った。

\section{（4）緑地保全および河川施策と基盤整備の歴史的変遷}

当該地域に導入されてきた緑地保全計画施策について，公園緑 地，風致地区，東京緑地計画，防空空地，戦災復興特別都市計画 に基づく緑地地域の指定，「東京都市計画河川下水道調査特別委員

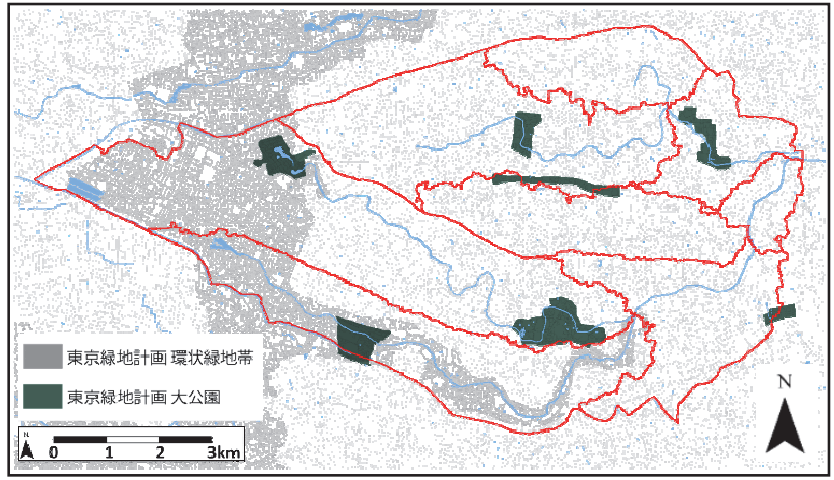

図－2＼cjkstart神田川上流域における東京緑地計画＼cjkstart計画地区

会」の答申 (1961 年) 等, 主要な施策が導入された地区について 図面化し分析を行った。基盤整備については, 江戸期の新田開発, 明治から大正期の耕地整理，その後の土地区画整理事業等を図化 した。

\section{（5）小流域分析に基づく緑被率・緑地構造の分析}

緑地保全施策と基盤整備を重ね合わせ緑地構造の特質について 考察を行った。緑地の質については, 植生調査を行い, 住宅地の 緑地についてはArcGIS 10.5 を用いて, 航空写真から NDVI (正 規化植生指標）12)を求め緑被率を算出した。

\section{表－1＼cjkstart神田川上流域における土地利用の変遷}

\begin{tabular}{|c|c|c|c|c|c|c|c|c|c|c|c|c|}
\hline \multirow{2}{*}{$\begin{array}{l}\text { 小流域 } \\
\text { 土地利用 }\end{array}$} & \multicolumn{2}{|c|}{ 神田川流域 } & \multicolumn{2}{|c|}{ 善福寺川流域 } & \multicolumn{2}{|c|}{ 妙正寺川流域 } & \multicolumn{2}{|c|}{ 江古田川流域 } & \multicolumn{2}{|c|}{ 桃園川流域 } & \multicolumn{2}{|c|}{ 計(神田川上流域) } \\
\hline & 1909年 & 2011年 & 1909年 & 2011年 & 1909年 & 2011年 & 1909年 & 2011年 & 1909年 & 2011年 & 1909年 & 2011年 \\
\hline 樹林地・公園 & $250.3 \mathrm{ha}$ & 79.9 ha & $244.4 \mathrm{ha}$ & $90.5 \mathrm{ha}$ & $132.5 \mathrm{ha}$ & $36.4 \mathrm{ha}$ & $26.4 \mathrm{ha}$ & $12.9 \mathrm{ha}$ & $71.1 \mathrm{ha}$ & $15.0 \mathrm{ha}$ & $832.5 \mathrm{ha}$ & 287.0 ha \\
\hline 川! 池 - 用水路 & $.6 \mathrm{ha}$ & $15.3 \mathrm{ha}$ & $.9 \mathrm{ha}$ & $19.7 \mathrm{ha}$ & 4.4 ha & 6.4 ha & $1.8 \mathrm{ha}$ & $1.1 \mathrm{ha}$ & $2.4 \mathrm{ha}$ & $0.1 \mathrm{ha}$ & $69.3 \mathrm{ha}$ & $52.2 \mathrm{ha}$ \\
\hline 水田 & $133.7 \mathrm{ha}$ & $0.0 \mathrm{ha}$ & $159.0 \mathrm{ha}$ & $0.0 \mathrm{ha}$ & 128.4 ha & $0.0 \mathrm{ha}$ & $55.3 \mathrm{ha}$ & $0.0 \mathrm{ha}$ & $84.4 \mathrm{ha}$ & $0.0 \mathrm{ha}$ & $719.9 \mathrm{ha}$ & $0.0 \mathrm{ha}$ \\
\hline 畑·空地 & 608.6 ha & $17.0 \mathrm{ha}$ & $1207.7 \mathrm{ha}$ & $35.0 \mathrm{ha}$ & 826.7 ha & 27.4 ha & 314.1 ha & $5.7 \mathrm{ha}$ & 383.9 ha & $0.0 \mathrm{ha}$ & 4056.3 ha & 85.4 ha \\
\hline 住宅地等 & $72.4 \mathrm{ha}$ & $634.4 \mathrm{ha}$ & 173.2 ha & $1029.0 \mathrm{ha}$ & $143.0 \mathrm{ha}$ & 730.2 ha & $62.7 \mathrm{ha}$ & 239.6 ha & $62.4 \mathrm{ha}$ & $386.0 \mathrm{ha}$ & $716.7 \mathrm{ha}$ & 3690.8 ha \\
\hline 道路 & 32.7 ha & $179.8 \mathrm{ha}$ & $61.2 \mathrm{ha}$ & $310.3 \mathrm{ha}$ & $27.3 \mathrm{ha}$ & 227.5 ha & $11.5 \mathrm{ha}$ & $101.6 \mathrm{ha}$ & $18.5 \mathrm{ha}$ & $116.9 \mathrm{ha}$ & $198.3 \mathrm{ha}$ & $1196.4 \mathrm{ha}$ \\
\hline 鉄道 & $0.0 \mathrm{ha}$ & $14.7 \mathrm{ha}$ & $4.4 \mathrm{ha}$ & $10.1 \mathrm{ha}$ & $0.0 \mathrm{ha}$ & $7.6 \mathrm{ha}$ & $0.0 \mathrm{ha}$ & $0.0 \mathrm{ha}$ & $3.4 \mathrm{ha}$ & $12.2 \mathrm{ha}$ & $9.3 \mathrm{ha}$ & $54.8 \mathrm{ha}$ \\
\hline
\end{tabular}

注）表－1の住宅地等は，図一 1 に表示した，住宅地・間地・社寺・墓地・学校・工場・特殊建築を含むものである。 


\section{4. 歴史的変遷に関する分析}

\section{（1）土地利用の歴史的変遷}

1909 年の土地利用と 2011 年の土地利用の東京都 GIS データ との比較検討を行った。流域全体として, 住宅地は 717ha から, 3,690 haに, 道路は 198ha から 1,196ha と増大した。その一方で, 水田は 719ha から 0.01 ha 一激减し, 畑地も 4,056ha から 85 ha となった。川・池・用水路等は, $69 \mathrm{ha}$ から $52 \mathrm{ha}$ の変化であるが, 神田川，善福寺川，妙正寺川流域では，護岸工事や治水対策のた め面積の増大が見られたが，江古田川流域では 35\%，桃園川流域 では 95\%以上が消失したことがわかった（表－1）。

\section{（2）緑地保全施策の歴史的変遷}

緑地保全と公園整備については, 1917 年に東京初の「郊外公園」 として，井の頭恩賜公園が開園した。1930 年には善福寺，1933 年には和田堀, 野方に風致地区が指定された。1939 年に策定され た「東京緑地計画」では, 神田川沿いに放射環状緑地帯が計画さ れ，都心に緑地が貫入する構造となっており，23 区外縁を環状緑 地帯で囲繞する計画が策定された。緑地帯の枢要部は，都市計画 緑地として決定された。高井戸・和田堀・善福寺・野方 (1942 年決定告示), 井の頭・妙正寺 (1943 年決定告示) である。その 後, 戦災復興計画において，ほぼ同じエリアに緑地地域が指定さ れたが，急激な都市化の波の中で改廃を遂げ，新都市計画法の公 布に伴い，「土地区画整理事業をすべき区域」として今日に至って いる。緑地構造を形成する基盤となっている河川については, 1961 年 10 月, 東京都市計画下水道調査特別委員会は, 河川と下 水道のあり方について答申を行い，「源頭水源を有しない 14 河川 の一部または，全部を暗渠化し下水道幹線として利用する」もの とした。当時，下水道の整備が行き渡っておらず，家庭や工場か ら流れる排水により河川の污濁が深刻であったことに起因してい る。これに伴い桃園川が覆蓋化され，下水道幹線となった。

\section{（3）基盤整備の歴史的変遷}

基盤整備については, 江戸期に玉川上水, 千川上水が開削され, 善福寺川上流部の台地上に短冊状の区割りを有する新田開発が行 われた。関東大震災の発生に伴い, 急速な郊外地一の住宅建設が 進む中で, 1925 年, 井荻村の村長, 内田秀五郎は, 井荻村土地区 画整理組合を設立し，10 年の歳月をかけ，1935 年に区画整理事 業を完成させた。これは, 総面積 888ha, 組合員役員総数は 132 名, 単一町村独自で行ったものとしては, 全国有数の規模であり, 東京の優れた郊外住宅地の形成を先導するものとなった。しかし ながら, その後, 神田川上流域においては, 計画的な基盤整備事 業が展開されることなく, 戦災復興特別都市計画に基づく緑地地 域が，「土地区画整理をすべき地区」となり現在に至っている。

\section{5. 緑地施策と基盤整備の重ね合わせに基づく分析}

緑地保全施策と基盤整備の組み合わせることにより，当該地域
表一2 緑地施策と基盤整備の重ね合わせによる類型化

\begin{tabular}{|c|c|c|c|c|c|c|c|}
\hline \multirow[b]{2}{*}{ 類型 } & \multicolumn{3}{|c|}{ 緑地保全·公園創出施策 } & \multicolumn{2}{|c|}{ 基盤整備 } & \multirow[b]{2}{*}{ 面積 } & \multirow[b]{2}{*}{ 割合 } \\
\hline & $\frac{\text { 都市計画公園 }}{\text { (2011） }}$ & $\begin{array}{c}\text { 風致地区 } \\
(2008)\end{array}$ & $\begin{array}{c}\text { 緑地地域 } \\
\text { (最終) }\end{array}$ & 江戸〜大正期 & 大正期 現代 & & \\
\hline A & 0 & 0 & 0 & 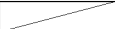 & 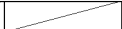 & $52.7 \mathrm{ha}$ & $0.9 \%$ \\
\hline B & 0 & 0 & - & 0 & 0 & $10.2 \mathrm{ha}$ & $0.2 \%$ \\
\hline $\mathrm{C}$ & $\mathrm{O}$ & $\begin{array}{ll}- \\
-\end{array}$ & 0 & 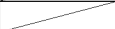 & 0 & $47.4 \mathrm{ha}$ & $0.8 \%$ \\
\hline D & 0 & - & - & $\infty$ & 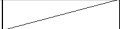 & 117.8 ha & $2.1 \%$ \\
\hline E & - & 0 & - & - & - & 47.0 ha & $0.8 \%$ \\
\hline F & - & 0 & 0 & - & - & 41.9 ha & $0.7 \%$ \\
\hline G & - & 0 & - & - & 0 & $17.0 \mathrm{ha}$ & $0.3 \%$ \\
\hline $\mathrm{H}$ & $\begin{array}{ll}- \\
-\end{array}$ & - & 0 & - & - & 360.4 ha & $6.4 \%$ \\
\hline 1 & - & - & - & 0 & - & 970.8 ha & $17.2 \%$ \\
\hline$\frac{1}{2}$ & - & - & - & - & 0 & $1533.8 \mathrm{ha}$ & $27.2 \%$ \\
\hline K & - & - & - & - & - & 2444.6 ha & $43.3 \%$ \\
\hline
\end{tabular}

には, 11 種の類型が存在することが分かった (表一2)。図一 3 は, これを図示したものである。以下，この 11 種の類型に基づき当 該地域における緑地構造の考察を行う。

\section{（1）類型ごとの特徵}

類型 $\mathrm{A} ， \mathrm{~B} ， \mathrm{C} ， \mathrm{D}$ は，都市計画公園であり都市計画公園・風 致地区・緑地地域が重複して指定されている。

類型 $\mathrm{E}$ は, 基盤整備は行われなかったが, 戦前より風致地区が 導入された地区であり, 和田堀公園を取り囲む一帯が指定されて いる。これは，風致地区が郊外の良好な住宅地を形成していくこ とを，一つの目的としていたことに起因する。

類型 $\mathrm{F}$ は, $\mathrm{E}$ と同様の目的を有するが，緑地地域の指定が行わ れており大規模緑地のネットワーク形成の視点が導入されている。 類型 $\mathrm{G}$ は, 善福寺公園の隣接地に限定したエリアであり, 井荻 土地区画整理事業と風致地区指定が同時に行われた地区である。

類型 $\mathrm{H}$ は, 緑地地域指定が最後まで維持された地区であり, 現 在は「土地区画整理事業を施行すべき地域」となっている。

類型 I は，江戸期新田開発により明治・大正期には既に住宅地 となっていたため, 緑地保全施策は導入されなかった地域である。

類型 $\mathrm{J}$ は，大正期以降，小規模な土地区画整理事業が行われ， 緑地保全施策は，ほとんど導入されなかった地域である。

類型 $\mathrm{K}$ は, 緑地保全施策・基盤整備の施策が全く導入されなか った地域であり，全体の $43.3 \%$ \% ここの類型に相当する。河川の 残存率は, 1909 年と 2012 年を比較し算定した。

\section{（2）小流域ごとの特徵と緑地構造及び緑被率}

\section{1）緑被率}

当該区域において公開されている東京都現存植生図の精度は, 1/25,000であるため参考にとどめるものとした。杉並区作成の「杉 並区夕どりの実態調査」（2012年）は，緑被率・樹木調査が実施 されているが $(1 / 10,000)$, 現存植生図は作成されていない。この ため, 小規模な緑地，緑地の質に関する情報が存在しないため, 以下の手順で作成を行った。まず，東京都都市計画地理情報シス テム土地利用現況調査レイヤーから，緑地の抽出を行った。この

\section{表一3 類型別にみた緑被率と河川残存率}

\begin{tabular}{|c|c|c|c|c|c|c|c|c|c|c|c|c|c|}
\hline \multirow[b]{2}{*}{ 類型 } & \multicolumn{2}{|c|}{ 神田川流域 } & \multicolumn{2}{|c|}{ 善福寺川流域 } & \multicolumn{2}{|c|}{ 妙正寺川流域 } & \multicolumn{2}{|c|}{ 江古田川流域 } & \multicolumn{2}{|c|}{ 桃園川流域 } & \multicolumn{2}{|c|}{ 神田川上流域全域 } & \multirow[b]{2}{*}{ 主な地名 } \\
\hline & $\begin{array}{c}\text { 緑被率 } \\
(\%)\end{array}$ & $\begin{array}{c}\text { 河川 } \\
\text { 残存率 } \\
(\%)\end{array}$ & $\begin{array}{c}\text { 緑被率 } \\
(\%)\end{array}$ & $\begin{array}{c}\text { 河川 } \\
\text { 残存率 } \\
(\%)\end{array}$ & $\begin{array}{c}\text { 緑被率 } \\
(\%)\end{array}$ & $\begin{array}{c}\text { 河川 } \\
\text { 残存率 } \\
(\%)\end{array}$ & $\begin{array}{c}\text { 緑被率 } \\
(\%)\end{array}$ & $\begin{array}{c}\text { 河川 } \\
\text { 残存率 } \\
(\%)\end{array}$ & $\begin{array}{c}\text { 緑被率 } \\
(\%)\end{array}$ & $\begin{array}{c}\text { 河川 } \\
\text { 残存率 } \\
(\%)\end{array}$ & $\begin{array}{c}\text { 緑被率 } \\
(\%)\end{array}$ & $\begin{array}{c}\text { 河川 } \\
\text { 残存率 } \\
(\%)\end{array}$ & \\
\hline $\mathbf{A}$ & - & - & 59.5 & 48.3 & - & - & - & - & - & - & 59.5 & 48.3 & 和田堀公園 \\
\hline B & - & - & 68.7 & 78.1 & - & - & - & - & - & - & 68.7 & 78.1 & 善福寺公園 \\
\hline C & 2.0 & 4.2 & 72.0 & 68.4 & - & - & - & - & - & - & 39.9 & 47.1 & 善福寺川緑地 \\
\hline D & 1.2 & 63.1 & 30.8 & 49.7 & - & - & - & - & - & - & 22.2 & 68.1 & 井の頭公園 \\
\hline $\mathbf{E}$ & 23.9 & - & 30.9 & - & - & - & - & - & - & - & 27.4 & - & 和田堀風致地区 \\
\hline $\mathbf{F}$ & 8.7 & - & 32.3 & 37.2 & - & - & - & - & - & - & 28.9 & 37.2 & 和田堀風致地区 \\
\hline $\mathbf{G}$ & - & - & 44.1 & - & - & - & - & - & - & - & 44.1 & - & 善福寺風致地区 \\
\hline $\mathrm{H}$ & 14.6 & 47.3 & 28.6 & 29.9 & 25.1 & - & 23.3 & - & - & - & 20.2 & 43.2 & 杉並区浜田山 \\
\hline$I$ & 15.8 & - & 16.1 & 74.6 & 22.9 & 0.0 & 8.0 & - & 10.9 & 0.0 & 15.9 & 49.0 & 武蔵野市吉祥寺 \\
\hline $\mathbf{J}$ & 14.9 & 65.2 & 17.9 & 75.9 & 19.1 & 16.5 & 16.2 & 8.8 & 11.0 & 0.0 & 17.4 & 32.0 & 杉並区井荻 \\
\hline $\mathrm{K}$ & 17.0 & 57.9 & 20.8 & 48.2 & 18.6 & 68.3 & 19.5 & 63.3 & 15.9 & 0.0 & 18.0 & 50.6 & 中野区野方 \\
\hline
\end{tabular}


うち公園, 緑地, 大規模な社寺地については，ブラウン・ブラン ケ法に基づき，現存植生調査を実施した。期間は 2017 年 8 月 9 月であり, 調查ステーション個所数は, 65 所であった。住宅地 の小規模な緑地については, マルチバンド航空写真を用いて，し きい值を $0.3 〜 0.4$ と設定し，NDVIがしきい值以上となる範囲を 抽出した。その後, 航空写真のピクセル值を用いた最尤法分類に より，非緑被地を除外し緑被率の算出を行った。

この結果，神田川上流域の平均緑被率は，32.9\%であった。し かしながら，実際の緑被率は地域によって大きく異なる。以下， 小流域分析に基づき，明らかにしていく(図一3参照)。

2）神田川小流域

神田川小流域は, 井の頭池を水源とする神田川の上流域であり, 神田上水の水源池としての井の頭池と御殿山は, 江戸近郊の名所 の一つであり，豊かな湧水と池畔の弁財天は人々の信仰の場とし て親しまれてきた。神田上水は自然流路と豊かな湧水を活用した 用水として，小石川の関口で大洗堰により分流が行われ，江戸市 民の飲料水として利用されていた。神田上水が廃止されたのは, 淀橋浄水場（現在の新宿副都心）の完成後の 1898 年であった。 水源池としての井の頭池と背後の御殿山は，手厚く保護されてお り明治期には帝室御料林であった。1913 年, 東京市では「郊外公 園設置」に関する発議がなされ，井の頭公園が，東京初の「郊外 公園」となり，爾来 100 年の時を刻んできた。東京緑地計画にお いて，当該地域は放射環状緑地带として位置づけられ拠点となる 大規模公園が配置され，戦後は緑地地域として指定された。しか しながら，都市化の進行の中で，改廃が相次ぎ，結果的に類型 $\mathrm{K}$ に相当する, 施策が全く導入されることのなかった地域が, $56.8 \%$ を占めている。しかしながら，拠点となる公園緑地がネットワー クされていることが，当該地域の特色である。

3）善福寺川小流域

善福寺川小流域は，善福寺池の水源林が手厚く保護され，善福 寺公園となっており, 中流域には, 大宮八幡宮が鎮座し, 和田堀 公園となっている。これらの拠点となる緑地の周辺は, 戦前より 風致地区として手厚く守られてきた。一方，基盤整備の観点から は，江戸期の新田開発（類型 I）及び井荻土地区画整理事業施工 地域（類型J）が，流域の 50\%を占めており，良好な住宅地が形
成されてきた。善福寺川小流域は，中流域において，河川沿いの 緑地のネットワークが途切れているが, 東京緑地計画策定時には, 既に，土地区画整理事業が竣工していたためと推察される。

\section{4) 妙正寺川小流域}

妙正寺川流域は，類型 J（上流部の井荻土地区画整理事業と， 下流部の小規模土地区画整理事業）と，類型 $\mathrm{K}$ (施策が導入され ず都市化が進展した地域）に二分される。前者においては，江戸 期から続く農家の屋敷林や畑が維持されており, 市民緑地の導入, 生産緑地法の改正など, 持続的維持に向けた努力が行われている。

5）江古田川小流域

江古田川流域は全域の 8 割以上を類型 $\mathrm{J}$ が占めている。当該地 域は都心に近いことから，大正末から昭和初期にかけて小規模な 土地区画整理事業が 9 地区において施行された。これらの事業は, 井荻土地区画整理事業に比べると緑地保全に対寸る配慮は，ほと んど行われず，江古田川の上流も河川空間が保全されることはな く消滅し, 今日に至っている。公園緑地としては, 江古田川が大 きく蛇行する地に段丘崖を保全し継承されてきた「江古田の森公 園」が保護樹林として残されている。下刚りが行われて更新され てきたクヌギ・コナラの雑木林から, シラカシ, シロダモ, スダ ジイの混在する常落混交林一の遷移が進んでいる。

6）桃園川小流域

基盤未整備エリアである類型 $\mathrm{K}$ が流域の $81.5 \%$ 占める。当該 区域には, 風致地区およひ緑地地域等の緑地保全施策は, 全く導 入されなかった。加えて, 桃園川の水源は, 井の頭池や善福寺池 のような武蔵野の段丘崖に起因寸る湧水ではなく，世田谷区の烏 山地区と同様に, 宙水に起源するものであるため, 周辺地域の都 市化に伴い，水源の枯渇が進展したものと考えられる。前述した 1961 年に提出された「東京都市計画下水道調査特別委員会の答 申」により暗渠化され，上部は緑道として整備されている。この ため河川空間は, 当該地域には存在していない。最も大面積を占 める類型は K 類型であり，緑被率は $15.9 \%$ となっている。

\section{（3）歴史的に蓄積されてきた GI 構造の分析}

GI は, 自然環境の総体を意味するものではなく, 国土交通省の GI 戦略に示されたように, 社会資本整備の中で保全・整備された もの，もしくは，その方針が示されたものあることから，本研究

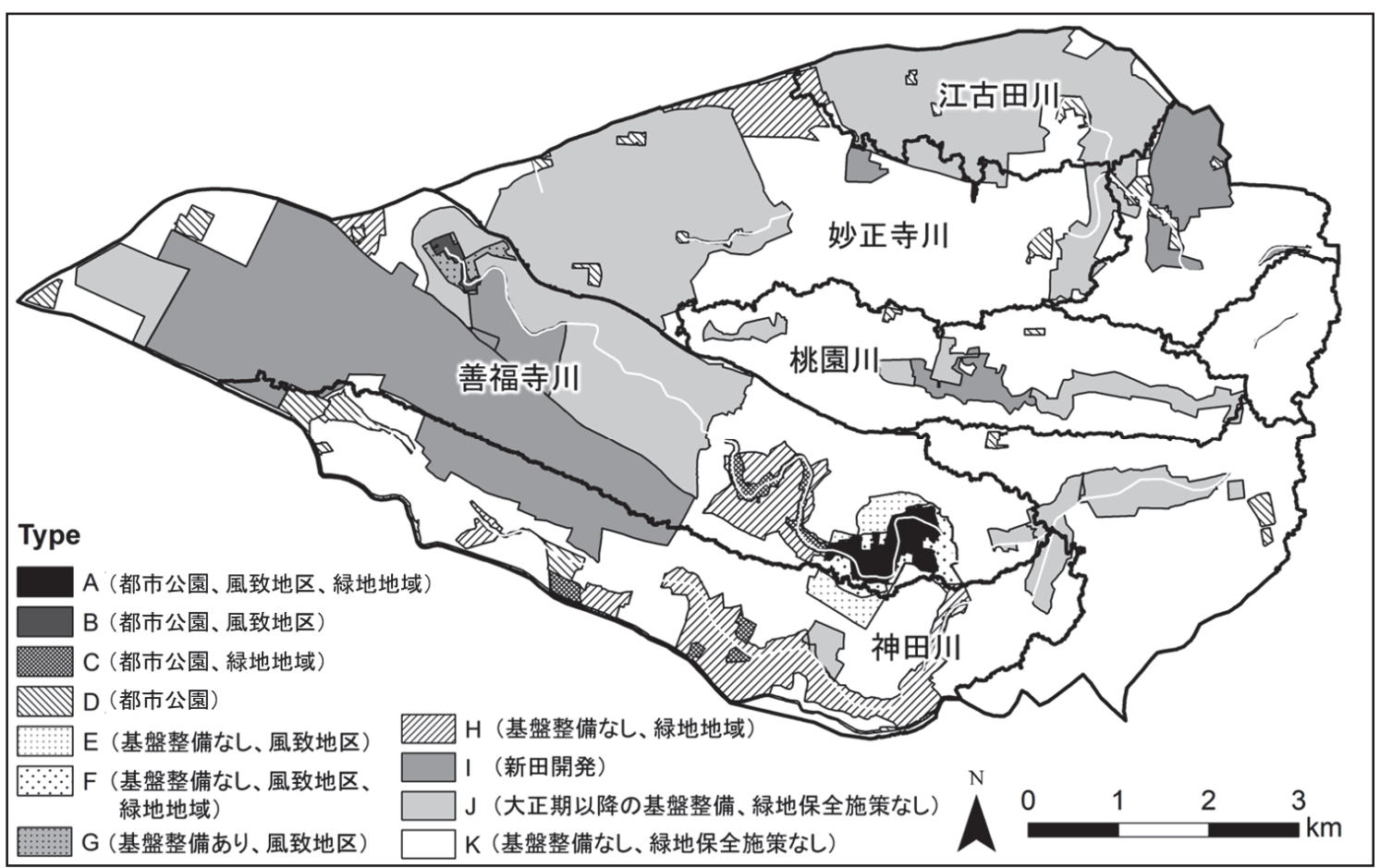

図－3 緑地施策と基盤整備の重ね合わせによる類型化図 
において分析を行った緑地は, GI としての基本的要件をみたして おり, 構造は以下の通りである。類型 A D は, 武蔵野台地の崖 線に起因する湧水地周辺に社寺仏閣が営まれ, 近代化の中で公園 となり，多様な保全施策が適用され，GI 拠点（コア）が形成され てきた。河川沿いの低平地および隣接する崖線沿いの緑地は，東 京緑地計画において放射環状緑地带として位置づけられたことか ら, その後の様々の施策において継承され，GI 拠点 (コア) が創 り出されてきた。これらを繋ぐものが, 河川空間であり, 桃園川, 井草川等を除き, 覆蓋化されず, 連続した水辺空間（コリダー） を提供している。一方，市街化された地域の緑地，即ち基質とな るマトリクスは，基盤整備の相違により小流域ごとに大きく異な っており, GI の創出に向けた施策の検討が必要であることが分か った。以上の考察から導きだされた当該地域の GI の構造図を示 したものが, 図ー4である。

\section{GI 構造を踏まえた戦略的計画論に関する検討}

\section{（1）対象地における緑の基本計画の現状と課題}

当該区域では，杉並区，中野区，武蔵野市で緑の基本計画が策 定されている。いずれも，身近な緑をまもり，育てることに重点 がおかれており，あわせて緑の質を高めること，緑でまちをつな げることが目標となっている。本研究は，今後の緑地施策の展開 により，生物多様性の向上，水循環の回復，温暖化に伴う都市型 水害の緩和等に寄与しうることを目的とするため，現行の緑の基 本計画の内容の精査を行った。

第一に生物多様性の向上については，具体的方法論が，2 区 1 市とも，ほとんど明示されていない。これは緑地データに生態系 情報が，導入されていないことに起因している。第二に，水循環 の回復については，杉並区では雨水の地下浸透化の促進と水辺環 境の再生・創出 ${ }^{13)}$ ，中野区では水とみどりの循環の推進 14), 武蔵 野市では玉川上水，千川上水の保全 ${ }^{15)}$ が述べられているが，豊か に存在する湧水の持続的維持・再生等については, 記載されてい ない。第三に，当該地域の大きな問題である都市型水害を緩和す るための緑地の果たす役割については，ほとんど言及されていな い。このように, 身近な生活環境を豊かにしていく目標となる「緑 の基本計画」は，地球環境問題の顕在化という，大きな変化の前 に，方法論自体を抜本的に変革すべき岐路にあるといえる。

\section{（2）戦略的計画論構築に向けた基礎的視点}

計画論の構築にあたっては, 目標設定・分析・評価・計画・施 策に至る一連のプロセスを展開寸る「枠組み」の設定が必要であ る。本研究では, この「枠組み」に階層的視点を導入し, 地域レ ベルでは，江戸以来継承されてきた小流域圈，小流域圈内の骨格 軸については，コア・コリダー，そして暮らしと共にある緑をマ トリクスとし，これを計画論構築の基本的視点として据えた。

\section{（3）基盤情報・GI マップの整備}

地球環境問題に都市計画のレベルから取り組むためには，気候 変動予測のダウンスケーリング化が必須であり, 基盤情報の構築 が必要である。当該地域においては, 石川等9)が 2 つ小流域 GI マップを作成しているが，本研究では，神田川上流域の 5 つの小 流域全体を網羅するGI マップの開発を行った。GI マップは, 生 物多様性, 水循環, 文化的景観の 3 つ軸を統合したものであり, 従来の土地利用や植生（樹林地・畑・水辺地等）に基づく緑地分 布図や緑被地摘出図とは，異なるものである。

\section{(4) GI プランニングの特質}

小流域・GI 構造・GI マップの整備により, 課題である地球環 境問題への取り組みについて, 以下の点が GI プランニングの特 質として，展開が可能となる。

生物多様性については, GI マップより, 生態系の質の情報を取 得することができる。一例を，図—5の GI ユニット（P101）に つい示す。P101 は, 「段丘崖・急傾斜地の落葉広葉樹林（林床 保全型)」であり，イヌシデ，クヌギなどが優占する。急傾斜地で あるため, 崩落地に先駆的に侵入するムクノキ, ミズキ等が混生 するが，林床はアズマネザサの群落であり小動物の生息地として 重要である。GI マップから, 緑地の質を読夕取り, 生態系の回廊 の形成に向け，具体的な指針を提供寸ることが可能となる。

水循環に関しては，当該地には 1063 年創建の大宮八幡宮があ り豊かな湧水が維持されてきた。御米橋湧水は東京都の湧水 57 選にも数えられる名水であったが, 2017 年に突然, 枯渇し現在に 至る。因果関係は不明であるが, 2016 年より同地点において河川 改修事業が開始されている。GI マップの最終雨水浸透能のデータ を活用し地下水流動モデルを構築し, 湧水再生に向けた基礎的研 究と施策の提言を行うこと等が可能である ${ }^{16)}$

都市型水害の軽減については, 小流域圏の導入により雨水の総

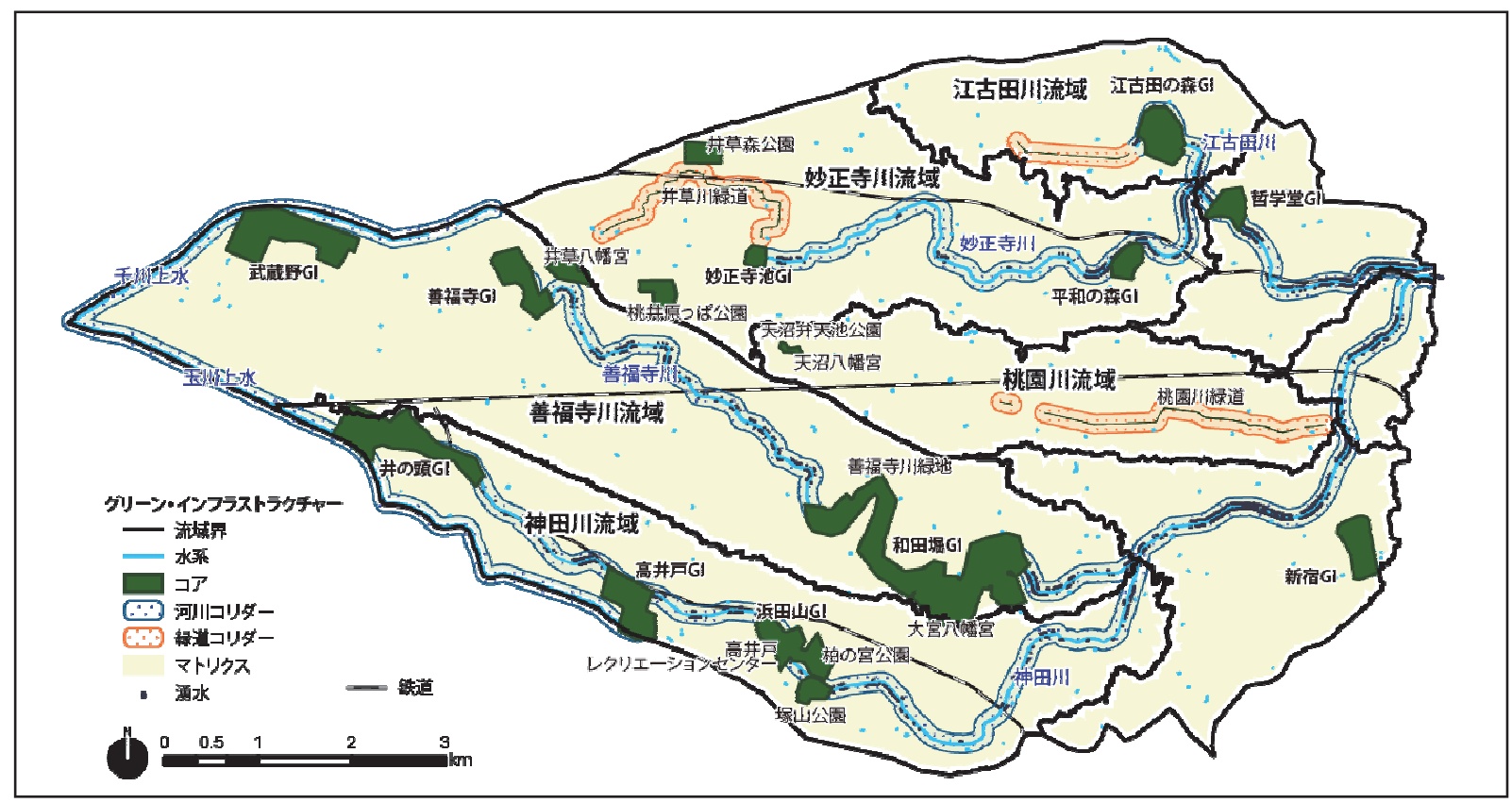

図一4＼cjkstart神田川上流域におけるグリーンインフラの構造図 


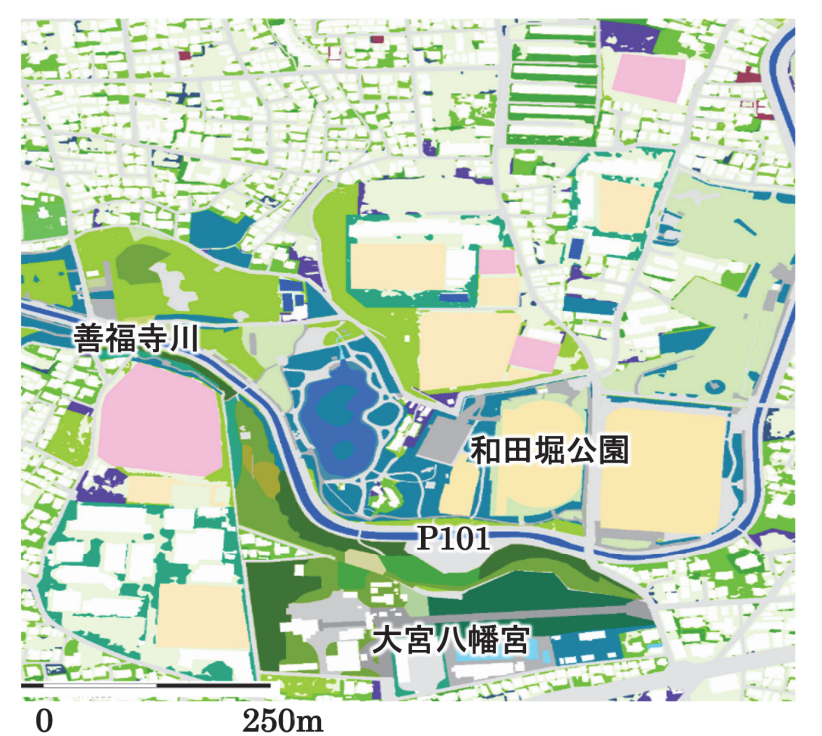

図-5 GI マップ

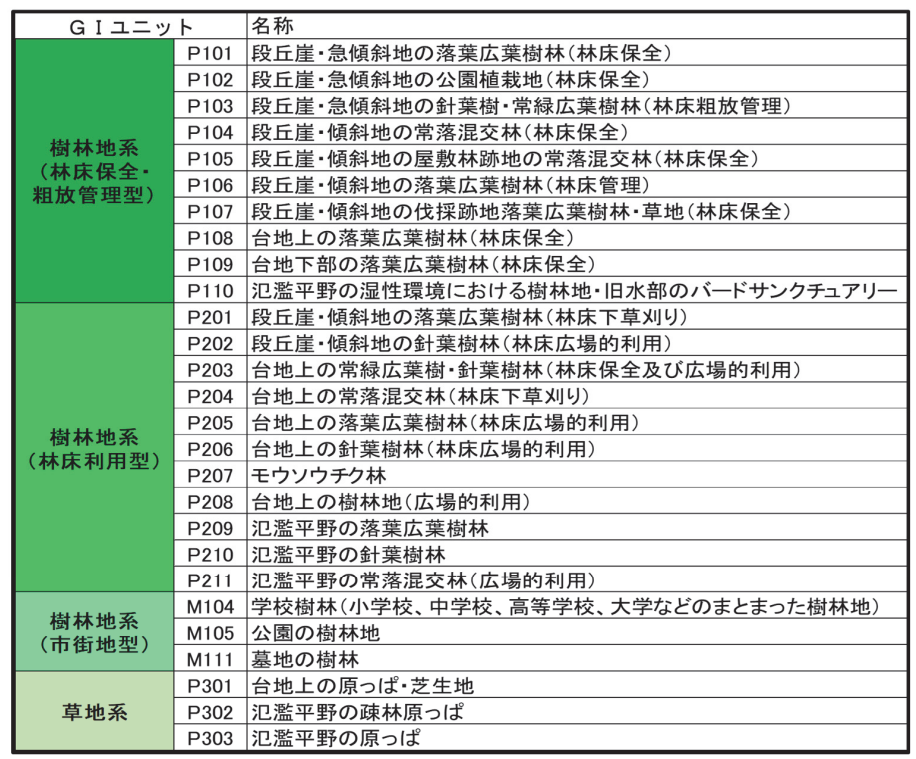

（和田堀公園周辺区域）

（最終閲覽＼cjkstart令和 2 年 2 月 18 日）

2) Natural England, What is Green Infrastructure, http://publications.naturalengland.org.uk/publication/35033 (最終閲 覧 令和 2 年 2 月 18 日)

3）木下剛・橋本慧・苁京禄（2016）：リバプールグリーンインフラスト ラクチャー戦略にみる小地域を対象とした計画手法, ランドスケープ 研究，79(5)，681-684

4) United States Environmental Protection Agency, Green Infrastructure, https://www.epa.gov/green-infrastructure/Whatgreen-infrastructure（最終閲覧 令和 2 年 2 月 18 日）

5）国土交通省（2015）: 国土形成計画（全国計画)，平成 27 年 8 月 14 日 閣議決定

6) 国土交通省 (2015) : 第 4 次社会資本整備重点計画, 平成 27 年 9 月 18 日閣議決定

7）国土交通省（2019）：「グリーンインフラ推進戦略」, http://www.mlit.go.jp/common/001297373.pdf（最終閲覧 令和 2 年 2 月 18 日）

8）竹内智子・石川幹子（2007）: 神田川上流域における公園緑地施策の 変遷に関する研究 : 都市計画論文集, 42(3), 7-12

9) Ishikawa, M., Negishi, Y. and Yamashita, H. (2018) : A Study on Green Infrastructure Planning in Highly Urbanized Area Towards the Climate Change and Bio-diversity, A Case Study in the Kanda River Basin, Tokyo, 2018 International Conference of Asian-Pacific Planning Societies, 4 Smart Infrastructure and Environment, 29

10）飯田晶子・大和広明・林誠二・石川幹子 (2015) : 神田川上流域におけ る都市緑地の有する雨水浸透機能と内水汇濫抑制効果に関寸る研究, 都市計画論文集, 50(3), 501-508

11）東京都: 東京都都市計画地理情報システムデータ:「平成 23,24 年度 土地利用現況（区部，多摩部)」2011年，2012 年

12) Tucker, C.J. (1979) : Red and Photographic Infrared Linear Combinations for Monitoring Vegetation, Remote Sensing of Environment, 8(2),127-150

13）杉並区 (2010) :杉並区みどりの基本計画, 20-21,26, 33

14）中野区 (2019): 中野区夕どりの基本計画, 37,46

15) 武蔵野市 (2019) : 武蔵野市緑の基本計画, 24-25, 29,36

16）根岸勇太・田原康博・山本遼介・小西裕喜・石川幹子（2019）: 健全な 水循環の形成に向けたグリーンインフラ活用シナリオと地下水流動シ ミュレーション, 環境情報科学論文集 33, 277-282

( 2019. 9. 28 受付 , 2020.3. 30受理) 